\title{
Association Between Depression and Cardiometabolic Risk Factors in Adolescents with Obesity ${ }^{\S}$
}

\section{Aşırı Ağırlıklı ve Şişman Ergenlerde Depresyon ve Kardiyometabolik Risk Etmenlerinin Ilişkisi}

\author{
Asli Okbay Gunes ${ }^{1} \oplus$, Rahime Hulya Bingol Caglayan ${ }^{2} \oplus$, Ezgi Sen Demirdogen ${ }^{2} \oplus$, Selmin Kose ${ }^{3 \oplus}$ \\ Ethem $\operatorname{Erginoz}^{4 \oplus}$, Oya $\operatorname{Ercan}^{5} \oplus$, Mujgan Alikasifoglu ${ }^{6} \odot$
}

${ }^{1}$ Department of Pediatrics, Istanbul University, Cerrahpasa Medical Faculty, Istanbul, Turkey ${ }^{2}$ Department of Child and Adolescent Psychiatry, Istanbul University, Cerrahpasa Medical Faculty, Istanbul, Turkey ${ }^{3}$ Departmant of Midwifery, Istanbul Bilim University, Istanbul, Turkey

${ }^{4}$ Department of Public Health, Istanbul University, Cerrahpasa Medical Faculty, Istanbul, Turkey

${ }^{5}$ Department of Pediatrics Division of Adolescent Medicine and Endocrinology, Istanbul University, Cerrahpasa Medical Faculty, Istanbul, Turkey ${ }^{6}$ Department of Pediatrics, Division of Adolescent Medicine, Istanbul University, Cerrahpasa Medical Faculty, Istanbul, Turkey

Received: 24.06.2020 / Accepted: 22.12.2020 / Published Online: 29.12.2020

Cite as: Okbay Gunes A, Bingol Caglayan RH, Sen Demiroren E, Kose S, Ergingoz, Ercan O, Alikasifoglu M. Association between depression and cardiometabolic risk factors in adolescents with obesity. Med J Bakirkoy 2020;16(4):385-91.

ABSTRACT

Objective: The aim of this study was to examine whether the presence of depression in overweight or obese adolescents increases the likelihood of cardiometabolic risk factors.

Method: We performed a retrospective cross-sectional analysis of the data obtained from overweight or obese, adolescents aged 11-18 years, who were evaluated in our clinic from January 2012 to December 2015. Depression was evaluated by "Children's Depression Inventory". Hypertension, dyslipidemia, hyperinsulinemia, hyperglycemia and insulin resistance were defined as cardiometabolic risk factors. The degree of obesity was calculated as the body mass index standard deviation score.

Results: Among 283 adolescents who were included in the study, 75 (26.5\%) were overweight, and 208 (73.5\%) were obese. The mean age was $14.02 \pm 1.67$ years and $168(59.4 \%)$ subjects were girls. The mean body mass index standard deviation score was $2.36 \pm 0.62$, The mean Children's Depression Inventory score was $12.72 \pm 6.5$, and $47(16.6 \%)$ of the participants were in depression. Depression was more frequently detected in females than in males $(p=0.047)$. Body mass index standard deviation score was in positive correlation with Children's Depression Inventory scores $(r=0.123, p=0.038)$. In univariate analyses, hyperinsulinemia was found to be 2.3 times more frequent in depressed group than in nondepressed group $(p=0.026)$. In logistic regression analysis this relation disappeared.

Conclusion: We showed that severity of depression increased, as the degree of obesity increased, but we could not find any clear relationship between depression and cardiometabolic risk factors in overweight or obese adolescents.

Keywords: Adolescents, cardiometabolic risk factors, degree of obesity, depression

Öz

Amaç: Bu çalışmanın amacı aşırı ağırıklı ya da şşsman ergenlerde depresyon varlığııın kardiyometabolik risk etmenlerini artırıp artırmadığını incelemektir.

Yöntem: Ocak 2012 - Aralık 2015 tarihleri arasında kliniğimizde değerlendirilen, 11-18 yaş arası aşırı ağırıklı ya da şişmanergenlerin verilerinin geriye dönük kesitsel çözümlemesi yapıldı. Depresyon, "Çocuklar için Depresyon Ölçeği" ile değerlendirildi. Hipertansiyon, dislipidemi, hiperinsülinemi, hiperglisemi ve insülin direnci kardiyometabolik risk etmenleri olarak tanımlandı. Şişmanlık derecesi, beden kitle indeksi standart sapma skoru olarak hesaplandı.

Bulgular: Calıșmaya alınan 283 ergenden 75'i (\% 26.5) aşırı ağırlıklı, 208'i (\% 73.5) șişmandı. Olguların yas ortalaması $14.02 \pm 1.67$ yıldı ve 168'i (\% 59.4) kızdı. Beden kitle indeksi standart sapma skoru ortalama değeri $2.36 \pm 0.62$, Çocuklar için Depresyon Ölçeği ortalama puanı $12.72 \pm 6.5$ idi ve katılımcıların 47'sinde (\% 16.6) depresyon saptandı. Depresyon sıklı̆ı kızlarda erkeklerden daha yüksek saptandı $(p=0.047)$. Beden kitle indeksi standart sapma skoru ile Çocuklar için Depresyon Ölçeği puanları arasında aynı yönlü anlamlı iliski saptandı $(r=0.123, p=0.038)$. Tek değişkenli çözümlemelerde depresyonu olanlarda hiperinsülinemi, depresyonu olmayanlara gören 2.3 kat daha sık bulundu $(p=0.026)$. Lojistik regresyon çözümlemesinde bu ilişki kayboldu.

Sonuç: Şişmanlığın derecesi arttıkça depresyonun şiddetinin arttığını gösterdik, ancak aşırı ağırlıkı ya da şişman ergenlerde depresyon ve kardiyometabolik risk etmenleri arasında bir ilişki bulamadık.

Anahtar Kelimeler: Ergenler, kardiyometabolik risk etmenleri, şişmanlığın derecesi, depresyon

${ }^{5}$ This study, "Association between depression and cardiometabolic risk factors in overweight and obese Turkish adolescents" was presented as oral presentation at 9th Europaediatrics Congress 2019, Dublin, Ireland.

Corresponding Author:

kasif@istanbul.edu.tr
A. Okbay Gunes 0000-0003-4041-0648

R.H. Bingol Caglayan 0000-0002-9414-7147

E. Sen Demirdogen 0000-0003-0120-6652

\author{
S. Kose 0000-0003-4958-6228 \\ E. Ergingoz 0000-0002-2338-4014 \\ O. Ercan 0000-0001-7397-2837
}

M. Alikasifoglu 0000-0002-0463-6597

(C) Telif hakkı Sağıık Bilimleri Üniversitesi Bakırköy Dr. Sadi Konuk Eğitim ve Araştırma Hastanesi'ne aittir. Logos Tıp Yayıncııı tarafindan yayınlanmaktadır. Bu dergide yayınlanan bütün makaleler Creative Commons Atf-GayriTicari 4.0 Uluslararası Lisansı ile lisanslanmıștı.

(c) Copyright Health Sciences University Bakırköy Sadi Konuk Training and Research Hospital. This journal published by Logos Medical Publishin

Licenced by Creative Commons Attribution-NonCommercial 4.0 International (CC BY) 


\section{INTRODUCTION}

The prevalence of adolescent obesity and depression is increasing, and these conditions are currently recognized as major public health concerns ${ }^{(1)}$. According to the data of the World Health Organization, the prevalence of overweightness and obesity increased to a great extent from 4\% in 1975 to $18 \%$ in 2016 in children and adolescents aged between 5 and 19 years ${ }^{(2)}$. It was shown that cardio metabolic risk factors, such as hypertension, insulin resistance, and dyslipidemia are more prevalent among children and adolescents with obesity compared to their normal -weight peers ${ }^{(3)}$. It has also been shown that there is a strong association between obesity and some mental health disorders such as depression and anxiety ${ }^{(4,5)}$. In overweight or obese children and adolescents the prevalence of depression was reported to be $10.4 \%$ in a previous study, and the prevalence of depressive symptoms has been reported to be $21.73 \%$ in a recent meta-analysis $(5,6)$.

A bi-directional relationship was established between obesity and depression in adolescents ${ }^{(1)}$. It was displayed that adolescents with depression had a $70 \%$ higher risk of becoming obese. On the other hand, obese adolescents had a $40 \%$ greater risk of being depressed ${ }^{(1)}$. The association was found to be stronger for the depression causing obesity compared to the obesity causing depression ${ }^{(1)}$. In a review focused specifically on shared biological pathways that may influence the bi-directional association between depression and obesity, it was considered that genetic factors, changes in certain homeostatic regulatory systems (hypothalamic-pituitary-adrenal axis [HPA], immunoinflammatory activation, neuroendocrine regulators of energy metabolism and microbiome) and brain circuits that combine homeostatic and mood regulatory responses, might have an impact on this relationship ${ }^{(4)}$. Insulin and dysregulation of leptin are also considered as factors that may represent a mediating mechanism in the obesity-depression relationship ${ }^{(4)}$. Psychological and behavioral factors may also influence this relationship. For example, disordered eating attitutes and behaviours were found to be associated with both depression and obesity ${ }^{(7,8)}$.

The association of depression with cardiovascular risk factors has also been widely recognized in both children and adults ${ }^{(9,10)}$. A scientific statement from the
American Heart Association indicated that major depressive disorder and bipolar disorder were tier II moderate risk factors for accelerated atherosclerosis and early cardiovascular disease in young individuals (10). However, young individuals with major depressive disorder and bipolar disorder who have more than one risk factor (obesity, hypertension, smoking, suboptimal physical activity) should be considered tier I high-risk group and implementation of more aggressive interventions are needed for this group ${ }^{(10)}$. In the light of the literature, the aim of this study was to examine whether the presence of depression in overweight or obese adolescents increased the likelihood of cardiometabolic risk factors.

\section{MATERIAL and METHODS}

We obtained retrospective data from medical records of overweight or obese adolescents aged between 11 to 18 years who attended our Medical Faculty Adolescent outpatient clinic from January 2012 to December 2015, in order to evaluate the association between depression and cardiometabolic risk factors. In our adolescent outpatient clinic, we routinely calculate the body mass index (BMI) of the patients irrespective of their admission complaints, and if we determined that the patient was overweight/obese, we evaluated him/her for the cardiometabolic risk factors that might be associated with obesity. The included patients were either admitted to our clinic for weight management or for an acute transient health problem and were found to be overweight/obese in routine evaluation. Between January 2012 to December 2015, four different studies with overweight/obese adolescents were conducted in our clinic. For this study, the cases in those four studies were retrospectively screened and those evaluated with Children's Depression Inventory (CDI) were included in this study (8,11-13). Pubertal patients who met the criteria for definition of overweightness/obesity established by Cole et al. ${ }^{(14)}$ according to age and gender and had been evaluated with CDI were included in this study. Patients with any chronic disease (except for being overweight/ obese and having overweightness/obesity associated complications such as hypertension, disordered glucose metabolism and dyslipidemia) and endogenous obesity of any etiology (such as hypothyroidism, etc.) were excluded from the study. Pubertal staging was performed in accordance with the Tanner staging sys- 
tem ${ }^{(15)}$. Testicular volume was evaluated using the Prader orchidometer in boys and recorded. Telarche in girls and a testicular volume of $4 \mathrm{~mL}$ in boys were considered as puberty ${ }^{(15)}$. Age, gender, weight, height, blood pressure, total cholesterol, triglyceride, HDL cholesterol, LDL cholesterol, fasting blood glucose and insulin levels of the adolescents were recorded from the patients' files.

Weight status was classified on the basis of measured height and weight obtained at the time of physical examination and BMI was calculated using the following formula: $\mathrm{BMl}=$ weight $/$ height $^{2}\left(\mathrm{~kg} / \mathrm{m}^{2}\right)^{2}{ }^{(2)}$. Patients with BMIs between 85th-95th persentiles were accepted as overweight and BMI values above 95th percentile as obese. ${ }^{(14,16)}$ The degree of obesity was calculated as the body mass index standard deviation score (BMISDS) by using age and gender specific to Turkish BMI percentiles which were generated by using lambda, mu, sigma (LMS) method, to standardize degree of obesity ${ }^{(14,17)}$. The LMS method provides a way of obtaining normalized growth centile standards which simplifies this assessment of growth standards and summarixes the data in terms of three smooth age- specific curves called L (lambda), M (mu), and S (sigma) ${ }^{(14) .}$

Hypertension, dyslipidemia, hyperinsulinemia, hyperglycemia and insulin resistance were defined as cardiometabolic risk factors. We used standard cut-off values for levels of fasting blood glucose (> $100 \mathrm{mg} / \mathrm{dl}$ ), total cholesterol ( $\geq 200 \mathrm{mg} / \mathrm{dl}$ ), HDL cholesterol ( $<40 \mathrm{mg} / \mathrm{dl}$ ), LDL cholesterol ( $\geq 130 \mathrm{mg} / \mathrm{dl}$ ) and triglycerides ( $\geq 130$ $\mathrm{mg} / \mathrm{dl}$ ) to define abnormal values ${ }^{(18)}$. Homeostasis model assessment of insulin resistance was calculated using the equation: HOMA-IR=fasting insulin $(\mu \mathrm{U} / \mathrm{mL}) \mathrm{x}$ fasting glucose $(\mathrm{mg} / \mathrm{dL}) / 405^{(19,20)}$. Fasting insulin levels above $30 \mu \mathrm{U} / \mathrm{mL}$ were accepted as cut-off levels for hyperinsulinemia and the HOMA-IR cut-off point for diagnosis of insulin resistance was accepted as 3.16 $(19,20)$. Seated blood pressure (BP) was measured after the adolescent had been resting quietly for 10 minutes using auscultator method. We used standardized blood pressure tables in which abnormal BP values were defined as those above the 95th percentile ${ }^{(21)}$.

Depression was evaluated by the Children's Depression Inventory (CDI): This inventory is comprised of 27 items which can be applied to children aged between 6 and 17 years. Its Turkish version has a high internal consis- tency (Cronbach $\alpha=0.77)^{(22)}$. The participants are asked to choose the option that is most appropriate for their condition during the last two weeks. Each item is scored as 0, 1 or 2 according to symptom severity. The highest score is 54 . The recommended cut-off point is 19. The subjects who scored higher than 19 in CDI, were referred to a psychiatrist for clinical evaluation and treatment for depression.

\section{Statistical Analyses}

The Statistical Package for Social Sciences (SPSS) version 21.0 statistical package was used for statistical analyses. The data were assessed for normality using visual and analytic methods. Continuous variables were expressed as mean \pm standard deviation and categorical variables as percentages. Correlation analysis was planned if a cardiometabolic risk factor was found to be associated with CDI score in univariate analysis to evaluate whether this risk factor was also associated with BMI-SDS. Chi-square test was used to compare categorical variables. In the assessment of the relationship between CDI score, BMI-SDS and other cardiometabolic risk factors, Pearson's correlation test was used. Logistic regression analyzes were conducted to determine the factors which were independently associated with depression. Variables with a $p$ value $<0.25$ in univariate analyses were accepted as independent variables. The enter method was used in the logistic regression model.

\section{RESULTS}

Among 283 adolescents with a BMI at the 85th percentile or higher; 75 (26.5\%) were overweight, and 208 (73.5\%) were obese. The mean age was $14.02 \pm 1.67$ years and 168 (59.4\%) of the subjects were girls. The mean BMI value was found to be $30.13 \pm 3.71 \mathrm{~kg} / \mathrm{m}^{2}$ and the mean BMI-SDS value was $2.36 \pm 0.62 \mathrm{~kg} / \mathrm{m}^{2}$. The mean CDI score was $12.72 \pm 6.5$, and $47(16.6 \%)$ of the parcipitans had CDI scores higher than 19.

The depression frequency was found to be higher in females compared to males ( $p=0.047)$. Depression was observed in $20.2 \%$ of overweight and obese female, and in $11.3 \%$. of male adolescents. It was determined that being female increased the risk of depression 1.9 times among overweight and obese adolescents (Table 1). Any significant difference was not found in depres- 
Table 1. Differences in gender, body mass indexes and cardiometabolic risk factors between depressed and nondepressed groups.

\begin{tabular}{|c|c|c|c|c|c|c|c|c|c|}
\hline \multirow[t]{3}{*}{ Variables } & & \multicolumn{4}{|c|}{ CDI scores } & \multirow[t]{3}{*}{ P value* } & \multirow[t]{3}{*}{ Odds ratios (OR) } & \multirow{2}{*}{\multicolumn{2}{|c|}{$95 \%$ confidence intervals }} \\
\hline & & \multicolumn{2}{|c|}{$<19$} & \multicolumn{2}{|c|}{$\geq 19$} & & & & \\
\hline & & $\mathbf{n}$ & $\%$ & $\mathbf{n}$ & $\%$ & & & Lower & Upper \\
\hline \multirow[t]{2}{*}{ Gender } & Female & 134 & 79.8 & 34 & 20.2 & \multirow[t]{2}{*}{0.047} & \multirow[t]{2}{*}{1.991} & \multirow[t]{2}{*}{0.999} & \multirow[t]{2}{*}{3.965} \\
\hline & Male & 102 & 88,7 & 13 & 11.3 & & & & \\
\hline \multirow[t]{2}{*}{ BMI $\left(\mathrm{kg} / \mathrm{m}^{2}\right)$} & Overweight & 66 & 88 & 9 & 12 & \multirow[t]{2}{*}{0.211} & \multirow[t]{2}{*}{1.639} & \multirow[t]{2}{*}{0.751} & \multirow[t]{2}{*}{1.916} \\
\hline & Obese & 170 & 81.7 & 38 & 18.3 & & & & \\
\hline \multirow[t]{2}{*}{ Hypertension (mm/hg) } & Yes & 51 & 85 & 9 & 15 & \multirow[t]{2}{*}{0.726} & \multirow[t]{2}{*}{0.868} & \multirow[t]{2}{*}{0.393} & \multirow[t]{2}{*}{1.916} \\
\hline & No & 182 & 83.1 & 37 & 16.9 & & & & \\
\hline \multirow[t]{2}{*}{ Total cholesterol (mg/dl) } & High & 195 & 81.9 & 43 & 18.1 & \multirow[t]{2}{*}{0.302} & \multirow[t]{2}{*}{0.567} & \multirow[t]{2}{*}{0.190} & \multirow[t]{2}{*}{2.334} \\
\hline & Normal & 32 & 88.9 & 4 & 11.1 & & & & \\
\hline \multirow[t]{2}{*}{ HDL- cholesterol (mg/dl) } & Low & 184 & 83.3 & 37 & 16.7 & \multirow[t]{2}{*}{0.843} & \multirow[t]{2}{*}{1.081} & \multirow[t]{2}{*}{0.501} & \multirow[t]{2}{*}{2.334} \\
\hline & Normal & 46 & 82.1 & 10 & 17.9 & & & & \\
\hline \multirow[t]{2}{*}{ LDL- cholesterol (mg/dl) } & High & 206 & 82.7 & 43 & 17.3 & 0.311 & 0.532 & 0.154 & 1.834 \\
\hline & Normal & 27 & 90 & 3 & 10 & & & & \\
\hline Triglyceride (mg/dl) & High & 172 & 82.3 & 37 & 17.7 & 0.481 & 0.762 & 0.357 & 1.625 \\
\hline & Normal & 61 & 85.9 & 10 & 14.1 & & & & \\
\hline Fasting blood glucose $(\mathrm{mg} / \mathrm{dl})$ & High & 33 & 80.5 & 8 & 19.5 & 0.589 & 1.262 & 0.542 & 2.938 \\
\hline & Normal & 203 & 83.9 & 39 & 16.1 & & & & \\
\hline Insulin $(\mu \mathrm{U} / \mathrm{mL})$ & High & 30 & 71.4 & 12 & 28.6 & 0.026 & 2.33 & 1.091 & 4.982 \\
\hline & Normal & 204 & 85.4 & 35 & 14.6 & & & & \\
\hline HOMA-IR & High & 155 & 82.9 & 32 & 17.1 & 0.807 & 1.087 & 0.556 & 2.126 \\
\hline & Normal & 79 & 84 & 15 & 16 & & & & \\
\hline
\end{tabular}

${ }^{*}$ chi-square test, CDI: Children's depression inventory, HOMA-IR: homeostatic model assessment of insulin resistance ,BMI: body mass index

sion frequency between overweight and obese groups. The frequency of hypertension, dyslipidemia and insulin resistance was not significantly different between depressed and nondepressed groups. Hyperinsulinemia was found to be more frequent in the depressed group compared to the nondepressed group $(p=0.026)$. Among overweight and obese adolescents with and without hyperinsulinemia, the rates of depression were $28.6 \%$, and $14.6 \%$, respectively.The frequency of hyperinsulinemia was found to be 2.3 times higher in patients with depression compared to those without (Table 1).

Using Pearson's correlation test, the BMI-SDS had positive correlation with CDI scores and insulin levels ( $r, p=$ $0.123,0.038 ; 0.341$, and 0.0001 , respectively). The correlations between CDI scores and BMI-SDS and cardiometabolic risk factors are given in Table 2 .

In logistic regression analysis, no factors were found to be independently associated with depression (Table 3).
Table 2.Relationship between depression scores, degree of obesity and cardiometabolic risk factors (Pearson's correlation test).

\begin{tabular}{|l|c|c|c|c|c|c|}
\hline & \multicolumn{2}{|c|}{ Whole group } & \multicolumn{2}{|c|}{ Female } & \multicolumn{2}{|c|}{ Male } \\
\hline & $\mathrm{r}$ & $\mathrm{p}$ & $\mathrm{r}$ & $\mathrm{p}$ & $\mathrm{r}$ & $\mathrm{p}$ \\
\hline Age & .047 & .431 & .049 & .530 & .027 & .773 \\
\hline SDS-BMI & .123 & .038 & .108 & .165 & .050 & .596 \\
\hline SBP(mmHg) & -.095 & .112 & -.060 & .445 & -.113 & .231 \\
\hline DBP(mmHg) & .031 & .610 & .045 & .570 & .039 & .683 \\
\hline $\begin{array}{l}\text { Total cholesterol } \\
\text { (mg/dl) }\end{array}$ & -.061 & .314 & -.090 & .253 & -.050 & .606 \\
\hline $\begin{array}{l}\text { HDL- cholesterol } \\
\text { (mg/dl) }\end{array}$ & -.069 & .251 & -.050 & .526 & -.160 & .091 \\
\hline $\begin{array}{l}\text { LDL- cholesterol } \\
\text { (mg/dl) }\end{array}$ & -.009 & .875 & .003 & .966 & -.034 & .717 \\
\hline Triglyceride (mg/dl) & -.058 & .336 & -.030 & .701 & -.103 & .276 \\
\hline $\begin{array}{l}\text { Fasting blood glucose } \\
\text { (mg/dl) }\end{array}$ & -.044 & .462 & -.049 & .531 & -.023 & .808 \\
\hline Insulin ( $\mu \mathrm{U} / \mathrm{mL}$ ) & & .103 & .084 & .083 & .286 & .140 \\
\hline HOMA-IR & .105 & .080 & .112 & .286 & .078 & .409 \\
\hline
\end{tabular}

CDI: Children's depression inventory $D B P$ : diastolic blood pressure

SDS-BMI: body mass index standard

SBP: systolic blood pressure ment of insulin resistance 
Table 3. Associations between depression and gender, obesity and hyperinsulinemia (depression was the dependent variable in logistic regression analysis).

\begin{tabular}{|l|c|c|c|c|c|}
\hline $\begin{array}{l}\text { Vari- } \\
\text { ables }\end{array}$ & Beta & $\begin{array}{c}\text { Signifi- } \\
\text { cance }\end{array}$ & $\begin{array}{l}\text { Odds } \\
\text { ratios }\end{array}$ & \multicolumn{2}{|c|}{$\begin{array}{c}\text { 95\% confidence } \\
\text { intervals }\end{array}$} \\
\cline { 4 - 6 } & & & & Lower & Upper \\
\hline Female & 0.700 & 0.051 & 2.014 & 0.996 & 4.074 \\
\hline Obesity & 0.454 & 0.276 & 1.575 & 0.696 & 3.560 \\
\hline $\begin{array}{l}\text { Hyper- } \\
\text { insu- } \\
\text { linemia }\end{array}$ & 0.651 & 0.108 & 1.918 & 0.867 & 4.242 \\
\hline
\end{tabular}

Gender (1=male vs 2=female), degree of obesity (1=overweight vs 2=obese) and hyperinsulinemia ( $n o=0$ vs yes $=1$ ) were the independently associated variables with depression

\section{DISCUSSION}

In our study, we found that the severity of depression increased, as the degree of obesity increased, and the frequency of depression was $16.6 \%$ in overweight or obese Turkish adolescents. Similar to our results, it was shown that higher BMI levels were associated with depressive symptoms in young individuals and this association was shown to be mediated by body image perception in one study ${ }^{(23)}$. Also in another study, it was found that depression was associated with more severe obesity in young individuals who were seeking treatment for obesity ${ }^{(24)}$. In a recent review, it has been reported that the prevalence of depression in obese children and adolescents was found to range between $1.8 \%$ and $63.7 \%$ in different studies, and the overall prevalence of depression among obese children and adolescents was $10.4 \%{ }^{(6)}$. In our study, the frequency of depression was found to be higher in female adolescents compared to male adolescents. However, it cannot be concluded that female gender increases the frequency of depression to a greater extent compared to overweight or obese male adolescents, though we found a $p$ value of $<0.05$, because the confidence interval included 1 . This result may be related to the small sample size of our study. In the literature, there are some studies indicating that obes female adolescents were more likely to develop depression compared to their male counterparts ${ }^{(1,25,26)}$. This condition may be related to the complex developmental processes that female adolescents confront during puberty ${ }^{(1,27)}$.

In the literature, it was shown that there is a relation- ship between depression and obesity ${ }^{(4-8)}$. Both depression and obesity were reported to be associated with an increase in cardiometabolic risk factors both in adolescents and adults ${ }^{(3,9,10)}$. Plausible biological mechanisms exist between depression and cardiometabolic risk factors, however, these mechansims are still not well understood. In some studies, it was suggested that alterations in the HPA axis might play an important role in the pathophysiology of depression and cardiometabolic disease and most of the studies in this topic evaluated adults ${ }^{(4,28-30)}$. A large percentage of subjects with depression have autonomic imbalance which is characterized by increased sympathetic activation and abnormal HPA activity ${ }^{(4,28)}$. Moreover, activation of the HPA axis leads to increased secretion of corticotrophinreleasing factor which results in excess cortisol secretion ${ }^{(30,31)}$. Cortisol is known to be a counter-regulatory hormone which is associated with type 2 diabetes, insulin resistance, dyslipidemia, and hypertension ${ }^{(29,30)}$. As cortisol levels were not evaluated in our study, we cannot draw conclusion about the effects of cortisol level on cardiometabolic risk factors in depressed adolescents.

In this study, in univariate analysis hyperinsulinemia was found to be more frequent in the depressed group compared to the nondepressed group. However, in logistic regression analysis, this relationship disappeared. When we analyzed the relationships between CDI scores, insulin levels and BMI-SDS by using Pearson's correlation test, and we found that there were significant correlations between the CDI scores, insulin levels and BMI-SDS. For this reason, hyperinsulinemia was considered an outcome of obesity rather than depression. Gross et al. (9) demonstrated that depression was associated with HDL-cholesterol, triglycerides, and metabolic syndrome cluster score in children and adolescents aged between 8 and 18 years across a wide range of BMls (normal weight to severe obesity). However, these relationships were not significant when body fat percentage was controlled. In that study, it was interpreted that the correlation between depression and cardiovascular disease risk factors might be emerging at least during childhood, but excess adiposity rather than depression might play a greater role in exacerbating the risk ${ }^{(9)}$. Our results might be speculated to support Gross et al.'s ${ }^{(9)}$ study, as the association between depression and hyperinsulinemia was not significant after controlling for degree of obesity in 
logistic regression analysis.

We examined a range of cardiometabolic risk factors in this study; however, our study has certain methodologic limitations. Firstly, the cross-sectional retrospective design did not allow us to examine the causes of depression and the effects of depression on future health of the participants. Secondly, there may be other factors including family background (single or separated parents, siblings, socio-economic status), sleep disorders, tobacco use, disordered eating attitudes, inadequate physical activity that were not examined in this study ${ }^{(10,32,33)}$. Thirdly, depression was assessed by self-reports of the study participants only, so the diagnosis of depression might be under/overdiagnosed.

In conclusion, adolescents with both depression and obesity might have a greater risk for future morbidity and mortality compared to adolescents who are only depressed or only obese. However the relationship between depression and cardiometabolic risk factors in overweight or obese adolescents remain elusive. Therefore, all adolescents should be screened for both obesity and mood disorders periodically, and especially overweight or obese adolescents should be followed up closely in terms of depression.

Ethics Committee Approval: Because the study was retrospective, ethics committee approval could not be obtained.

Conflict of Interest: No conflict of interest was declared by the authors.

Funding: No funding was used for this study. Informed Consent: Because the study was retrospective, patient consent could not be obtained.

\section{REFERENCES}

1. Mannan M, Mamun A, Doi S, Clavarino A. Prospective Associations between Depression and Obesity for Adolescent Males and Females- A Systematic Review and Meta-Analysis of Longitudinal Studies. PLoS One. 2016;11(6):e0157240. https://doi.org/10.1371/journal.pone.0157240

2. World Health Organization. Obesity and overweight, Factsheet Updated February 2018 [internet]. Available from: http://www. who.int/en/news-room/fact-sheets/detail/obesity-and-overweight (Accsesd: 15 August 2019).

3. Reinehr T, Andler W, Denzer C, Siegried W, Mayer H, Wabitsch M. Cardiovascular risk factors in overweight German children and adolescents: relation to gender, age and degree of overweight. Nutr Metab Cardiovasc Dis. 2005;15(3):181-7.

https://doi.org/10.1016/j.numecd.2004.06.003

4. Milaneschi $\mathrm{Y}$, Simmons WK, van Rossum EFC, Penninx BW. Depression and obesity: evidence of shared biological mechanisms. Mol Psychiatry. 2019;24(1):18-33. https://doi.org/10.1038/s41380-018-0017-5

5. Wang $S$, Sun $Q$, Zhai L, Bai Y, Wei W, Jia L. The prevalence of depression and anxiety symptoms among overweight/obese and non-overweight/non-obese children/adolescents in china: A systematic review and meta-analysis. Int J Environ Res Public Health. 2019 26;16(3):340. https://doi.org/10.3390/ijerph16030340

6. Sutaria S, Devakumar D, Yasuda SS, Das S, Saxena S. Is obesity associated with depression in children? Systematic review and meta-analysis. Arch Dis Child. 2019;104(1):64-74. https://doi.org/10.1136/archdischild-2017-314608

7. Lazarevich I, Irigoyen Camacho ME, Velázquez-Alva MDC, Zepeda Zepeda M. Relationship among obesity, depression, and emotional eating in young adults. Appetite. 2016;107:639-44. https://doi.org/10.1016/j.appet.2016.09.011

8. Okbay Güneş $A$, Alikaşifoğlu $M$, Şen Demirdöğen $E$, et al. The relationship of disordered eating attitudes with stress level, bone turnover markers, and bone mineral density in obese adolescents. J Clin Res Pediatr Endocrinol. 2017;9(3):237-45. https://doi.org/10.4274/jcrpe.3794

9. Gross AC, Kaizer AM, Ryder JR, et al. Relationships of anxiety and depression with cardiovascular health in youth with normal weight to severe obesity. J Pediatr. 2018;199:85-91. https://doi.org/10.1016/j.jpeds.2018.03.059

10. Goldstein B, Carnethon MR, Matthews KA, et al. Major depressive disorder and bipolar disorder predispose youth to accelerated atherosclerosis and early cardiovascular disease: A scientific statement from the American Heart Association. Circulation. 2015;132(10):965-86. https://doi.org/10.1161/CIR.0000000000000229

11. Güneş $A O$, Alikaşifoğlu $M$, Erginoz $E$, et al. The relationship between cardiometabolic risks and vitamin D levels with the degree of obesity. Turk Pediatri Ars. 2019;54(4):256-63. https://doi.org/10.14744/TurkPediatriArs.2019.98372

12. Sönmez HE, Canpolat N, Ağbaş A, et al. The relationship between the waist circumference and Increased carotid Intima thickness in obese children. Child Obes. 2019;15(7):468-75. https://doi.org/10.1089/chi.2019.0022

13. Çelik $E$, Bingöl $H$, Alikaşifoğlu $M$, İpek $N$, Demirpençe $D$. Overweight in adolescents: Impact of a cognitive behavioral intervention program on weight management in depressive overweight adolescents. Turk Pediatri Ars. 2013;48(Özel Sayı 2):103. Available from: https://www.journalagent.com/tpa/ pdfs/TPA_48_SUP_2_1_149.pdf\#page=104

14. Cole TJ, Bellizzi MC, Flegal KM, Dietz WH. Establishing a Standard definition for child overweight and obesity worldwide: international survey. BMJ. 2000;320(7244):1240-3. https://doi.org/10.1136/bmj.320.7244.1240

15. Bundak R, Neyzi O. Normal büyüme. In: Cinaz $P$, Darendeliler $F$ Akıncı A, Özkan B, Dündar BN, Abacı A, Akçay T, editors. Çocuk Endokrinolojisi. İstanbul: Nobel Tip Kitabevi; 2013. p. 21-9.

16. Köse S, Yıldız S. Motivational support programme to enhance health and well-being and promote weight loss in overweight and obese adolescents: A randomized controlled trial in Turkey. Int J Nurs Pract. 2020;e12878. https://doi.org/10.1111/ijn.12878

17. Neyzi O, Bundak R, Gökçay G, et al. Reference values for weight, height, head circumference, and body mass Index in Turkish children. J ClinRes Pediatr Endocrinol. 2015;7(4):280-93. https://doi.org/10.4274/jcrpe.2183

18. Expert Panel on Integrated Guidelines for Cardiovascular Health and Risk Reduction in Children and Adolescents; National Heart, Lung, and Blood Institute. Expert panel on integrated guidelines for cardiovascular health and risk reduction in children and adolescents: summary report. Pediatrics. 2011;128(Suppl 5):S21356. https://doi.org/10.1542/peds.2009-2107C

19. Keskin M, Kurtoglu S, Kendirci M, Atabek ME, Yazici C. Homeostasis model assessment is more reliable than the fasting glucose/insulin ratio and quantitative insulin sensitivity check index for assessing insulin resistance among obese children and 
adolescents. Pediatrics. 2005;115(4):500-3. https://doi.org/10.1542/peds.2004-1921

20. Kurtoğlu S, Hatipoğlu N, Mazıcıoğlu M, Kendirici M, Keskin $M$ Kondolot $M$. Insulin resistance in obese children and adolescents: HOMA-IR cut-off levels in the prepubertal and pubertal periods. J ClinRes Pediatr Endocrinol. 2010;2(3):100-6. https://doi.org/10.4274/jcrpe.v2i3.100

21. Flynn JT, Kaelber DC, Baker-Smith CM, et al. Clinical practice guideline for screening and management of high blood pressure in children and adolescents. Pediatrics. 2017;140(3):e20171904. https://doi.org/10.1542/peds.2017-1904

22. Öy B. Çocuklar için depresyon ölçeği geçerlik ve güvenirlik çalışması. Turk Psikiyatri Dergisi 1991;2:132-6.

23. Eidsdottir ST, Kristjansson AL, Sigfusdottir ID, Garber CE, Allegrante JP. Association between higher BMI and depressive symptoms in Icelandic adolescents: the mediational function of body image. Eur J Public Health. 2014;24(6):888-92. https://doi.org/10.1093/eurpub/ckt180

24. Fox CK, Gross AC, Rudser KD, Foy AM, Kelly AS. Depression, anxiety, and severity of obesity in adolescents: Is emotional eating the link? Clin Pediatr. 2016;55(12):1120-5. https://doi.org/10.1177/0009922815615825

25. Korczak DJ, Lipman E, Morrison K, Szatmari P. Are children and adolescents with psychiatric illness at risk for increased future body weight? A systematic review. Dev Med Child Neurol. 2013;55(11):980-7.

https://doi.org/10.1111/dmcn.12168

26. Muhlig Y, Antel J, Focker M, Hebebrand J. Are bidirectional associations of obesity and depression already apparent in childhood and adolescence as based on high-quality studies? A systematic review. Obes Rev. 2016;17(3):235-49.

27. Sylper AH. The pubertal timing controversy in the USA, and a review of possible causative factors for the advance in timing of onset of puberty. Clin Endocrinol (Oxf). 2006;65(1):1-8. https://doi.org/10.1111/j.1365-2265.2006.02539.x

28. Frasure-Smith N, Lesperance F, Irwin MR, Talajic M, Pollock BG. The relationships among heart rate variability, inflammatory markers and depression in coronary heart disease patients. Brain Behav Immun. 2009;23(8):1140-7. https://doi.org/10.1016/j.bbi.2009.07.005

29. Huffman JC, Celano CM, Beach SR, Motiwala SR, Januzzi JL. Depression and cardiac disease: epidemiology, mechanisms, and diagnosis. Cardiovasc Psychiatry Neurol. 2013;2013:695925. https://doi.org/10.1155/2013/695925

30. Gelaye B, Williams MA, Lemma S, et al. Major depressive disorder and cardiometabolic disease risk among sub-Saharan African adults. Diabetes Metab Syndr. 2015;9(3):183-91. https://doi.org/10.1016/j.dsx.2014.05.003

31. Carney RM, Freedland KE, Miller GE, Jaffe AS. Depression as a risk factor for cardiac mortality and morbidity: a review of potential mechanisms. J Psychosom Res. 2002;53(4):897-902. https://doi.org/10.1016/S0022-3999(02)00311-2

32. Miller GE, Cole SW. Clustering of depression and inflammation in adolescents previously exposed to childhood adversity. Biol Psychiatry. 2012;72(1):34-40. https://doi.org/10.1016/j.biopsych.2012.02.034

33. Palta JP, Samuel RL, Miller LE, Szanton LS. Depression and oxidative stress: Results from a meta-analysis of observational studies. Psychosom Med. 2014;76(1):12-9. https://doi.org/10.1097/PSY.0000000000000009 